УДК 378.011.3-057.175:174(073)

DOI: 10.37026/2520-6427-2020-103-3-167-172

\section{Василь КАПЛІНСЬКИЙ,}

доктор педагогічних наук, доцент, доцент кафедри педагогіки і професійної освіти Вінницького держсавного педагогічного університету імені Михайла Кочюбинського

\section{Ольга ПІНАСВА,}

кандидат педагогічних наук, доцент, дочент кафедри педагогіки і професійної освіти Вінницького держсавного педагогічного університету імені Михайла Кочюбинського

\title{
РОЛЬ НАВЧАЛЬНОЇ ДИСЦИПЛІНИ «ЕТИКА ВИКЛАДАЧА ЗАКЛАДУ ВИЩОЇ ОСВІТИ» У ПІДГОТОВЦІ МАГІСТРІВ СПЕЦІАЛЬНОСТІ 011 «ОСВІТНІ, ПЕДАГОГІЧНІ НАУКИ»
}

Навчальна дисципліна «Етика викладача закладу вищеӧ освіти» спрямована на формування у майбутніх педагогів моральних иінностей $і$ духовного стрижня особистості. У статті розкривається не лише ї̈ своєчасність, актуальність і важливість, а й сочіальна та психологічна значущість дотримання викладачем норм професійної етики. Оскільки моральні норми, принципи і правила більше формуються під впливом власного прикладу викладачів, аніж під впливом їхніх слів, значну увагу приділено особистісним характеристикам викладача вищої иколи, його спонуканню до самоаналізу власних учинків, визначенню типових помилок поведінки, пов'язаних із порушенням норм професійної моралі. Чітко визначено загальні й фахові компетентності, а також результати оволодіння навчальною дисиипліною. Зміст відображає сутність, принципи, методи, психологічні механізми морально-етичного виховання, яке покладено в основу формування морально-етичних иінностей.

Ключові слова: зміст навчальної дисцииліни, викладач, етика, мораль, духовність, моральне виховання, норми етичної поведінки.

Учебная дисчиплина «Этика преподавателя в учрежнении высшего образования» направлена на формования у будущих педагогов нравственных иенностей и духовного стержня личности. В статье раскрывается не только ее своевременность, актуальность и важность, но и сочиальная и психологическая значимость соблюдения преподавателем норм профессиональной этики. Поскольку моральные нормы, принципь и правила больше формируются под влиянием собственного примера преподавателей, чем под влиянием их слов, значительное внимание уделено личным характеристикам преподавателя высшей школь, его побуждению к самоанализу собственных поступков, определению типичных ошибок поведения, связанных с нарушением норм профессиональной морали. Четко определены общие и профессиональные компетентности, а также результаты овладения учебной дисииплиной. Содержание отражает сущчноть, принщипь, методы, психологические механизмы морально-этического воспитания, которое лежит в основе формирования моральноэтических иенностей.

Ключевые слова: содержание учебной дисчиилиHbl, преподаватель, этика, мораль, духовность, нравственное воспитание, нормы этического поведения.

The discipline "Ethics of a Higher School Teacher» is aimed at shaping the moral values and the spiritual core of future teachers. The article reveals the timeliness, relevance and importance of the discipline, as well as the social and psychological significance of the teacher's compliance with the norms of professional ethics. As moral norms, principles and rules are formed under the influence of teachers' own example rather than under the influence of their words, considerable attention is paid to the personal characteristics of a higher school teachers, their motivation to self-analysis of their own actions, identification of typical behavioral errors, connected with violation of professional ethics. General, professional competencies and results of mastering the discipline are clearly defined.

The objectives of the discipline are related to the disclosure of the psychological and social significance of the teacher's compliance with the professional ethics; acquaintance of higher education students with the norms and rules of ethical behavior; formation of experience of analysis and solution of moral and ethical problems 
that arise in the professional activity of a higher school teacher; formation of moral values and corresponding personality traits; gaining the experience in ensuring a mutual contact of the higher school teacher with colleagues and students and prevention of conflict situations; development of ethical culture in future teachers of higher education institutions on a reflexive basis, encouraging them to analyze their own actions; identification of common mistakes in the teacher's behavior, which are associated with a violation of professional morality; disclosure of features of ethical behavior of the teacher at the analysis of the complicated administrative situations; learning the technology of developing an algorithm for interaction with colleagues and students on an ethical basis.

Quite logically, the content reflects the essence, principles, methods, psychological mechanisms of moral and ethical education, as it underlies the formation of moral and ethical values. The topics related to the ethical norms of pedagogical communication of teachers with their colleagues and students, ensuring mutual contact, prevention and resolution of conflict situations are quite meaningful.

The role of the discipline is that the personal and professional development of the future higher school teacher cannot be complete without parallel spiritual improvement, just as technical progress will not be humane in moral and spiritual regress. In both cases, the disbalance will create obstacles to a quality result.

Key words: content of academic discipline, teacher, ethics, morality, spirituality, moral education, norms of ethical behavior.

Майбутнє людства залежить не від науково-технічного прогресу, а від моральності. A. Ейнштейн

Хто рухається вперед у знаннях, але відстає у моральності, той більше йде назад, аніж уперед. Аристотель

Постановка проблеми. Становлення особистості як науковий феномен активно обговорюється в сучасній гуманістичній філософії в межах дослідження ідеї самоцінності людини, її самореалізації як головної мети та сенсу життя. У зв'язку 3 цим Г. Батіщев розглядає людину як істоту, яка перебуває у постійному пошуку, а життя - як «стрімкий і неперервний потік, що утворює собою нові або оновлені схили берегів» [1, с. 103]. Таким чином, зрозуміти роль діяльності, досвіду, практики, зокрема й спеціальної та навчальної, допомагає твердження філософа про нероздільність самореалізації та духовності людини.

Сьогодні ми всі є свідками технічного прогресу за наявності морального та духовного регресу. Тобто, відбувається певний дисбаланс, коли техніка обганяє етику. Це надзвичайно небезпечно. I якщо XXI століття не буде століттям гуманізму, прогрес може призвести до серйозних проблем, навіть трагедій. Прогрес не повинен бути нелюдським.

Саме перед нами, освітянами, стоїть надскладне завдання - закласти основу людяності та сформувати хребет сучасної системи цінностей.

Моральні цінності студентів формуються передусім під впливом власного прикладу викладачів, аніж під впливом того, що вони говорять. Саме тому моральне виховання називають «вихованням без виховання».
Якщо в людині «живуть» духовні закони, в неї є внутрішній цензор, який сильніший за неї. Він корегує iii дії, вчинки, стримує, навіть іде проти іiі волі та бажань, допомагає керувати ними. Людина, яка ігнорує духовні закони, часто впадає в депресію. Психологічні тренінги, до яких часто вдається людина, при відсутності духовного стрижня можуть і не допомогти. Навпаки, вони навіть шкодять, адже єдине, до чого здатні, - лише «накачати» самооцінку як велосипедну шину. Відвідавши їх, людина отримує не саме щастя, а його ілюзію: нічого насправді не змінюється, лише зростає позитивна уява про себе. Образно кажучи, ці тренінги схожі на «допінг», який приймає спортсмен.

У кожної людини вироблений власний стереотип поведінки. Нерідко ми стаємо його жертвами. Зламати стереотип - це морока, незручно, боляче. Тому і живемо за інерцією, відповідно до звичок, які вже пустили коріння і стали хронічними, сподіваємося, що «якось воно буде».

Усе викладене вище переконує в актуальності, важливості й необхідності навчальної дисципліни «Етика викладача закладу вищої освіти» у підготовці магістрів спеціальності 011 «Освітні, педагогічні науки».

Аналіз наукових досліджень і публікацій. В основу професійної підготовки майбутніх здобувачів вищої освіти в умовах освітнього середовища закладів вищої освіти (далі - 3BO) покладено положення законодавчих і стратегічних документів, що окреслюють напрями розвитку освіти в Україні, забезпечення іiї якості, а саме: Закони України «Про освіту» (2017) та «Про вищу освіту» (2014), Національна стратегія розвитку освіти в Україні на 2012-2021 роки (2013), Концепція «Нова українська школа» (2016), Концепція розвитку освіти України на період 2015-2025 роки, галузева Концепція розвитку неперервної педагогічної освіти (2013), Стратегія сталого розвитку «Україна - 2020» (2015), Стратегія сталого розвитку України до 2030 року (проєкт) та ін.

Сутність проблеми полягає в тому, що теоретичне вивчення наукових підходів, концепцій, технологій не забезпечує повною мірою ефективного формування практичного досвіду, необхідного для майбутніх здобувачів вищої освіти у професійній діяльності. Саме на цих аспектах зосереджено увагу українських і зарубіжних учених, які досліджували формування професійно-педагогічної компетентності майбутніх здобувачів вищої освіти (Н. Бідюк, Н. Козлова, Т. Колодько, В. Орлов, К. Скиба); використання педагогічних технологій у професійній підготовці майбутніх фахівців (О. Гончарова, Ю. Жиляєва, Є. Полат); зміст і структуру професійної підготовки (Н. Авшенюк, В. Базуріна, I. Задорожна); створення освітнього середовища та нових інформаційних технологій в освіті (В. Биков, Я. Ваграменко, Р. Гуревич, А. Сршов, М. Жалдак, І. Захарова, М. Кадемія, Т. Коваль, Н. Морзе, Л. Петухова, Є. Полат, С. Сисоєва, О. Співаковський, О. Спірін, В. Сумський).

Мета статті полягає в розробленні системи підготовки майбутніх здобувачів вищої освіти спеціальності 011 «Освітні, педагогічні науки» 3 дисципліни «Етика викладача закладу вищої освіти» в умовах освітнього середовища закладу вищої освіти та перевірці її ефективності на практиці.

Виклад основного матеріалу. Архіважливим у контексті морального становлення викладача $\epsilon$ аспект, на якому наголошує В. Орлов, про те, що «концепція професійного становлення на особистісному 
рівні визначає становлення тієї частини культури фахівця, яка забезпечує духовне зростання, пов'язане 3 усвідомленням людиною сенсу життя і сенсу професійної діяльності» [7, с. 111]. Особистісно-професійне становлення відбуватиметься у правильному напрямі лише тоді, коли особа опиратиметься на духовні закони, без яких ні вона зокрема, ні суспільство в цілому не можуть існувати нормально. Згадаймо, що Спарта припинила своє існування саме $з$ тієї причини, що була «холодною» в духовному плані країною. Духовні закони, на думку К. Юнга, визначають духовний стан людини, яким обумовлено характер ії діяльності, зокрема й професійної, іiі творчості в науці, політиці, мистецтві, бізнесі тощо. «Людська свідомість, - стверджує філософ, - не може безкарно миритися 3 торжеством аморального. Як результат - виникають найтемніші інстинкти, які не тільки спотворюють людину, а й призводять до психічних патологій» [8, с. 24-26]. Відсутність духовного стрижня спричиняє духовну кризу, внаслідок якої особистість втрачає життєві орієнтири, які відповідно гальмують успішність професійної діяльності: духовна криза спричиняє кризу життя загалом. Навпаки, усвідомлення і внутрішне прийняття духовних законів робить людину стійкою, сильною, допомагає здобути владу над собою. Найвищий же рівень духовної культури настає тоді, коли людина контролює не тільки свої вчинки, а й свої думки.

Таким чином, особистісно-професійне становлення майбутнього педагога не може бути повноцінним без паралельного духовного вдосконалення, як і технічний прогрес не буде гуманним при моральному і духовному регресі. Як у першому, так і в другому випадках дисбаланс створюватиме перешкоди на шляху до якісного результату. Щоб уникнути такого дисбалансу, вважаємо за необхідне у підготовці магістрів спеціальності 011 «Освітні, педагогічні науки» викладати навчальну дисципліну «Етика викладача закладу вищої освіти».

Мета вивчення дисиилліни полягає у формуванні в майбутніх викладачів закладів вищої освіти морально-етичних цінностей через засвоєння етичної та професійної культури професійної діяльності на основі рефлексії.

Завданнями дисиипліни є: розкриття психологічної і соціальної значущості дотримання викладачем норм професійної етики; ознайомлення здобувачів вищої освіти 3 нормами та правилами етичної поведінки, принципами, сприяння їх засвоєнню; формування досвіду аналізу та розв'язання морально-етичних проблем, що виникають у професійній діяльності викладача закладу освіти; формування моральних цінностей та відповідних їм якостей особистості; набуття досвіду забезпечення взаємного контакту викладача закладу освіти 3 колегами і студентами та попередження конфліктних ситуацій; розвиток у майбутніх викладачів закладів вищої освіти етичної культури на рефлексивній основі, спонукання їх до аналізу власних учинків; визначення загальних помилок у поведінці викладача, що пов'язані з порушенням норми професійної моралі; розкриття особливостей етичної поведінки викладача при аналізуванні ускладнених управлінських ситуацій; навчання технології розробки алгоритму взаємодії 3 колегами та студентами на етичній основі.

У процесі вивчення дисципліни передбачено формування як загальних компетентностей (діяти соціально відповідально, виконуючи свої громадянські обов'язки; розвивати здатність до самоосвіти та особистісно-професійного самовдосконалення; володіти мовленнєвою культурою; працювати в команді, налагоджуючи конструктивну міжособистісну взаємодію з іншими суб'єктами спільної діяльності; усвідомлювати та критично аналізувати взаємозв'язки між культурними, соціальними та економічними процесами), так і фахових (здійснювати професійну діяльність відповідно до правових норм та юридичних документів у галузі освіти; спілкуватися українською та іноземними мовами з використанням спеціальної термінології в предметній галузі; конструктивно вирішувати складні педагогічні ситуації на основі застосування психолого-педагогічних знань; бути здатним до рефлексії та самовдосконалення, підвищення рівня власної педагогічної майстерності й культури; дотримуватися норм педагогічної етики та академічної доброчесності у професійній діяльності; здійснювати ефективні комунікації та етично грамотно розв'язувати конфліктні ситуації у професійній діяльності).

Інтеграція теоретичної та практичної складових етики викладача закладу освіти, а також їх засвоєння передбачає демонстрацію здобувачем вищої освіти таких результатів навчання: розуміти місце навчальної дисципліни в системі підготовки фахівця та іï взаємозв'язки з іншими галузями знань; уміти проводити критичний аналіз інформаційних джерел, освітніх, наукових і професійних текстів у галузі своєї спеціальності; знати і використовувати стратегії попередження та вирішення конфліктних ситуацій у педагогічному процесі; знати й застосовувати у професійній діяльності норми і принципи педагогічної етики; здійснювати психологічну саморегуляцію, вести здоровий спосіб життя у побуті та професійній діяльності; знати норми академічної доброчесності та наслідки за їх порушення; знати і застосовувати у професійному спілкуванні конструктивні стилі, способи і стратегії міжособистісної взаємодії.

Перший розділ навчальної дисципліни «Етика викладача закладу вищої освіти» містить два блоки тем: 1) теми, пов'язані $з$ етикою і мораллю; 2) теми, зміст яких відображає проблеми, пов'язані з морально-етичним вихованням особистості.

У першій, вступній, темі «Сутність і специфіка етики викладача закладу освіти» здобувачі вищої освіти ознайомлюються із сутністю і специфікою етики викладача закладу вищої освіти: іiї роллю у розвитку суспільства, предметом, метою, завданнями, категоріями (етичні стосунки, етична свідомість, етичні дії, професійний обов'язок), специфікою, загальними принципами, структурою і функціями, розкриває їі філософський характер. При цьому основна увага акцентується на етичних аспектах професійної поведінки педагога, його професійній гідності та педагогічному обов' язку як особливій формі відповідальності. Не залишається поза увагою й управлінська етика як спосіб регуляції поведінки у професійно-педагогічній діяльності. Прослідковується зв'язок етики викладача закладу вищої освіти з іншими навчальними дисциплінами, що вивчаються в процесі підготовки магістрів спеціальності 011 «Освітні, педагогічні науки».

Друга тема «Моральні норми управлінської діяльності викладача освітнього закладу» розкриває проблеми моралі та етики в історико-педагогічному контексті: основні етичні концепції, джерела та умови виникнення педагогічної етики, «Золоте правило» етичної системи», етична традиція Аристотеля, деонтологічна лінія Канта, онтологічна лінія Гегеля, 
призначення, сенс та гуманістична спрямованість педагогічної етики, морально-професійні норми та їх історичний розвиток, етичні погляди Г. Сковороди, В. Сухомлинського, К. Ушинського, А. Макаренка та інших видатних педагогів.

Зміст третьої теми «Вимоги до особистості викладача закладу освіти» відображає морально-етичні норми діяльності викладача закладу вищої освіти. Аналізується поняття моралі, взаємозв'язок етики і моралі, іiі соціальні функції, моральні норми та цінності як регулятори моральної поведінки, професійні норми як історично встановлені стандарти професійної поведінки та діяльності, часткові та рамкові норми, норми-ідеали, норми-заборони, норми-права, норми-обов'язки. Розкривається специфіка моралі, складові моралі та моральної поведінки, структура моральної свідомості, сутність добра і зла як провідних понять моральної свідомості й категорій моралі, зміст понять «справедливість», «обов'язок» «відповідальність», «совість», «гідність», «честь», «моральна практика». Здійснюється аналіз конкретно-історичного характеру розвитку норм професійної поведінки викладача закладу освіти, гуманізму як нормативної основи педагогічної професії, характеристика змісту основних нормативних вимог до діяльності педагога, існуючих кодексів професійної етики педагога в Україні та за ії межами.

Четверта тема «Етика та культура педагогічного спілкування» присвячена моральному вихованню як важливому фактору формування морально-етичних норм поведінки педагога. Акцент робиться на таких актуальних питаннях: моральне виховання як педагогічна проблема; спрямованість морального виховання на формування морального стрижня особистості (моральних поглядів, моральних переконань, моральної спрямованості); моральність і духовність. Розкриваються причини зниження рівня моральної культури та духовних криз особистості: негативний вплив навколишнього середовища та засобів масової інформації; подвійна суспільна мораль (декларація моральних цінностей на словах і низький рівень моральної культури в поведінці та діяльності); причини, пов'язані з недоліками виховної роботи закладів освіти; причини особистісного характеру (слабка воля, невміння контролювати свої бажання та дії, залежність від своїх «нездорових» пристрастей). Провідне місце у змісті теми належить етапам морального виховання: ознайомлення 3 морально-етичними нормами та їх засвоєння; внутрішнє прийняття норм, правил і принципів моральної поведінки на підставі формування позитивного ставлення до них; перехід засвоєних моральних норм, правил і принципів у моральні переконання; формування моральної спрямованості особистості; контроль думок.

П'ята тема «Моральна вихованість особистості, показники та методи ї̈ діагностування. Приниипи виховання морально-етичних норм поведінки» $є$ логічним продовженням попередньої теми, оскільки відображає результат морального виховання і зовнішні та внутрішні показники його оцінювання, до яких належать: поведінка, дії та вчинки; ставлення до інших, до себе, до виконання професійних обов'язків; зовнішній вигляд; рівень моральної свідомості тощо. У їх контексті цілком логічно розглядаються методи діагностування моральної вихованості: спостереження, спеціально створені ситуації, бесіда, вивчення продуктів діяльності. Вихідними положеннями, дотримання яких забезпечує ефективність виховання морально-етичних норм і правил поведінки, є принцип виховного впливу, а саме: позитивного ставлення до вихованця, опора на позитивне, поєднання вимогливості з повагою, об'єднання керівництва педагогів iз розвитком самодіяльності та ініціативи, єдність і систематичність виховних впливів, прихованість виховних впливів, врахування індивідуальних та вікових особливостей, емоційність, систематичність та наступність у формуванні морально-етичних норм.

Успішно сформувати морально-етичні норми майбутнього викладача закладу вищої освіти можливо лише за умови застосування оптимальних методів і прийомів, які розкриваються у змісті шостої теми «Методи виховання моральної свідомості як способи впливу на особистість з метою формування морально-етичних норм поведінки». Ї̈і складові: моральні норми, принципи, правила як регулятор моральної поведінки; свідомість, підсвідомість, діяльність, оцінювання та корекція як категорії, що лежать в основі класифікації методів морального виховання; роль методу прикладу як переконливого аргументу і зразка для наслідування в демонстрації привабливості тієї чи іншої моральної норми та вихованні зневаги до прояву негативного у поведінці; переконування як метод словесно-емоційного впливу на почуття, свідомість та поведінку для формування переконань, моральних рис та поглядів; умови його ефективності: ставлення до викладача, переконливість аргументів, уникнення повчань, почуття міри, моралізування, нотацій, що спричиняють протидію; врахування індивідуальних особливостей; моральна дискусія як обговорення проблеми, що передбачає суперечливі погляди; ситуації морального вибору; педагогічно доцільна самопрезентація; умови успішності конструктивної самопрезентації (тактовність, наявність внутрішньої культури, ерудиція, власної позиції, професіоналізм, почуття розумного та доречного гумору інше); маніпулятивні стратегії самопрезентації.

Із метою формування морально-етичної норми поведінки, оцінювання та корекцію також застосовуються відповідні методи, які у взаємозв'язку і взаємозалежності з психологічними механізмами розкриваються у змісті сьомої теми «Етика попередження та розв'язання конфліктів у діяльності викладача закладу освіти»: роль методів включення в діяльність у формуванні морально-етичних норм; метод виховних ситуацій: спеціально створені, природні, ситуації вибуху, ситуації морального вибору; спрямування природної ситуації у виховне русло; пряма та опосередкована вимога; рольова гра; доручення; привчання; методи оцінювання і корекції поведінки; неефективні та ефективні заохочення, вимоги до них (об'єктивність, несподіваність, гласність, урахування індивідуальних і вікових особливостей, урахування прикладених зусиль, порівняння минулих та теперішніх досягнень та ін.); покарання як метод корекції морально-етичної поведінки: за і проти; психологічні механізми формування морально-етичних норм поведінки як шляхи розвитку мотиваційно-ціннісної сфери особистості; ідентифікація як процес ототожнення себе з іншою людиною, внаслідок чого відбувається несвідоме присвоєння морально-етичних цінностей та способів поведінки; наслідування як цілеспрямоване відтворення манер, учинків і звичок інших людей; зовнішня та внутрішня конформність як зміна власної поведінки або поглядів внаслідок тиску групи; вживання в соціальну роль, внаслідок чого відбувається засвоєння 
особистістю норм і способів поведінки, яких вимагає iii соціальна роль; емоційне обумовлювання як шлях закріплення позитивної поведінки на основі виникнення позитивних емоцій і припинення негативної на основі виникнення негативних емоцій.

Другий розділ також містить два блоки тем: 1) теми, пов'язані з етикою взаємовідносин; 2) морально-етичне самовдосконалення викладача вищої школи.

Оскільки етика взаємовідносин детермінується особистісним чинником, восьма тема «Вимоги до особистості викладача закладу вищої освіти та морально-етичні принципи його поведінки» розкриває такі питання: складові педагогічного авторитету викладача закладу освіти в контексті морально-етичних вимог; педагогічні здібності та особистісні якості в контексті етики управління; професійний педагогічний обов'язок та професійна гідність викладача закладу освіти; штампи й стереотипи у поведінці педагога; неприпустимість і подолання в собі «управлінського чванства», зарозумілості, самовпевненості, безкомпромісності; конформізм і нонконформізм; наявність власної позиції та максимальний прояв індивідуальності; толерантність, тактовність, терпимість до інакомислення, прагнення до взаєморозуміння як складові морально-етичної культури викладача закладу вищої освіти; «професійні захворювання» (амбіційність, максималізм, підозрілість, уразливість) та проблеми, породжені ними, в педагогічному колективі; етика громадянськості політична культура і культура мови викладача.

Найбільш практико орієнтований характер має дев'ята тема "Етика та культура педагогічного спілкування», що розглядається як моральна цінність. На лекції і практичному занятті здобувачі вищої освіти аналізують проблеми спілкування в сучасному технізованому світі та віртуальній реальності, сутність, складники та функції педагогічного спілкування, сутність поняття «культура спілкування», етичні основи взаємовідносин викладача та студентів, питання психологічної сумісності й несумісності, роль викладача в організації продуктивного спілкування у педагогічному колективі (вміння ставити завдання, аргументовано переконувати, розподіляти «ролі» в колективі), морально-психологічні бар'єри спілкування, моральні проблеми взаємин у педагогічному колективі. Питання даної теми розглядаються в контексті переходу від суб'єкт-об'єктних до суб'єкт-суб'єктних відносин у спілкуванні в умовах демократизації суспільства й гуманізації освіти.

Логічним продовженням означеної вище теми $\epsilon$ десята тема «Етика відносин у системі «педагогnедагог»», у змісті якої вивчаються основні етичні принципи та норми діяльності викладача, загальні морально-психологічні основи професійно-ділового спілкування, сутність, структура та функції управлінської взаємодії, педагогічний такт викладача закладу освіти. Тема передбачає аналіз стилів управління, їх етичних аспектів та виховного потенціалу, умов відбору оптимального стилю, системи комунікативних умінь викладача. Важливе місце у змісті даної теми належить шляхам забезпечення взаємного контакту 3 педагогічним колективом на початковому етапі управлінської діяльності, комунікативно-педагогічним помилкам в управлінській діяльності, способам підтримування позитивних взаємостосунків із колективом у процесі управління. Розглядаються питання, пов'язані 3 морально-психологічним кліматом, формальними й неформальними відносинами в колективі, розподілом «ролей» у колективі («генератори ідей», «виконавці», «експерти», «критики» та ін.), професійно-діловими відносинами в педагогічному колективі: «по горизонталі» - 3 колегами, а «по вертикалі»3 адміністрацією, етикетом ділових відносин у неформальних умовах.

Блок тем, присвячених етиці педагогічного спілкування, завершує одинадията тема «Етика попередження та розв'язання конфліктів в діяльності викладача закладу освіти», в якій розкривається сутність понять «взаємний контакт», «конфлікт», «згода»; сутність поняття «педагогічний конфлікт», його структура, функції, динаміка, фази; особливості і причини конфліктів відносин, етичних конфліктів, конфліктів діяльності; визначаються основні функції педагога у вирішенні педагогічних конфліктів, етичні способи їх попередження та розв'язання в освітньому процесі; аналізуються в контексті морально-етичних норм прийоми виховного впливу викладача закладу освіти як способи розв'язання конфліктних ситуацій.

Зміст заключної, дванадиятої, теми «Морально-етичне самовдосконалення особистості: cуmність, етапи, організація» відображає аспекти цілеспрямованого самовпливу викладача 3 метою самовиховання, а саме: морально-етичне самовиховання як здатність свідомо та активно керувати своїми діями і поведінкою, задіюючи внутрішні механізми свого розвитку, його специфічні особливості; усвідомлення педагогом відповідальності за своє професійне майбутнє, активна протидія зовнішнім обставинам, планування та коригування власної поведінки і діяльності заради професійного успіху як передумови успішності морально-етичного самовиховання; сутність, етапи та умови ефективної організації морально-етичного самовиховання; реалізація самовиховуючого потенціалу змісту. Здійснюється аналіз спонукального (перехід інтересу до потреби, забезпечення його, прийняття рішення, бажання), цільового (самооцінка, постановка мети й завдань), організаційно-діяльнісного (програмування, включення у діяльність, спрямування на реалізацію програми, регулярність, активізація вольових зусиль) контрольно-регулювального етапів самовиховання та його бар'єрів (негатив від впливу оточення, звичка виконувати пізніше, відсутність систематичності й регулярності).

Важливими змістовими компонентами теми є: адекватна самооцінка, самопізнання і самоаналіз; способи самопізнання і самооцінки морально-етичних якостей (порівняння своїх результатів з ідеалом, спостереження за діями та вчинками інших людей i проведення паралелей з собою, прислуховування до зауважень та порад в особисту адресу); програма та індивідуальні плани морально-етичного самовиховання: план-мінімум «Крок уперед» (на день, тиждень, місяць) 3 обов'язковим аналізом виконаного, план-максимум «Перспективні кроки» (на семестр, рік і більш значний відрізок часу); вироблення власного кодексу правил і принципів, що визначають успішність морально-етичного самовиховання; вибір засобів морального самовдосконалення; систематичність та регулярність дій; самоконтроль; методи та прийомами морального самовиховання: самонавіювання, самопереконування, самонаказ, самосхвалення, самоконтроль, самозаохочення, самокритика тощо. 
Висновки. Пропонована нами навчальна дисципліна «Етика викладача закладу вищої освіти» спрямована на формування у майбутніх педагогів норм, принципів і правил морально-етичної поведінки, тобто духовного стрижня особистості. У ході аналізу розкрито соціальну та психологічну значущість дотримання викладачем норм професійної етики. Основний акцент зроблено на тому, що моральні цінності студентів передусім формуються під впливом власного прикладу викладачів, а не під впливом того, що вони говорять. Зважаючи на це, ключову увагу приділено особистісним характеристикам викладача вищої школи, його спонуканню до самоаналізу власних учинків, визначенню типових недоліків у поведінці, пов'язаних із порушенням норм професійної моралі. Цілком логічно зміст відображає сутність, принципи, методи, психологічні механізми морально-етичного виховання, оскільки саме його покладено в основу формування морально-етичних цінностей. Досить змістовними є теми, пов'язані 3 етичними нормами педагогічного спілкування викладача 3 колегами та студентами, забезпечення взаємного контакту, попередження та розв'язання конфліктних ситуацій. Чітко визначено загальні, фахові компетентності та результати оволодіння навчальною дисципліною.

Подальші дослідження у даному напрямі плануємо присятити питанням попередження та розв'язання конфліктів у діяльності викладача закладу освіти, зокрема й булінгу.

\section{СПИСОК ВИКОРИСТАНОЇ ЛІТЕРАТУРИ}

1. Батищев Г. С. Найти и обрести себя. Bопросы философии. 1995. № 3. С. 103-109.

2. Винославська О. В., Малигіна М. П. Людські стосунки : навч. посіб. Вид. 2-е, перероб. та доповн. Київ : Центр навчальної літератури, 2006. 142 с.

3. Каплінський В. В. Загальнопедагогічна підготовка до курсового та комплексного державного екзамену (осв.-квал. рівень «бакалавр»). Вінниця : ТОВ «Нілан-ЛТД», 2015. 104 с.

4. Каплінський В. Методика викладання у вищій школі : навчальний посібник. Вінниця : ТОВ «Нiланд-ЛТД», 2015. 222 с.

5. Каплінський В. В. 100 складних ситуацій на уроках та поза уроками: шукаємо рішення : навчальний посібник для майбутніх учителів. Київ : Центр навчальної літератури, 2017. 80 с.

6. Оболонский А. В. Этика публичной сферы и реалии политической жизни. Изд. 2-е, эл. Москва : Социум, 2020. 448 c. URL: https://rucont.ru/efd/719373 (дата звернення: 10.06.2020).

7. Орлов В. Професійне становлення особистості педагога у вимірах класичної методології. Науковий вісник Інституту професійно-технічної освіти НАПН Украӥни. Серія «Професійна педагогіка». 2014. № 8. C. 103-111.

8. Юнг К. Психология бессознательного. Пере. с англ. Изд. 2-е. Москва : Когито Центр, 2010. 352 с.

Дата надходження до редакиї: 03.08.2020 p.

Наталія ЛАВРИЧЕНКО, доктор педагогічних наук, професор кафедри іноземних мов та методики викладання

Глухівського начіонального педагогічного університету імені Олександра Довженка,

м. Глухів Сумської області
УДК 37.04

DOI: 10.37026/2520-6427-2020-103-3-172-177

\section{СОЦІАЛЬНО ОБДАРОВАНА ОСОБИСТІСТЬ: ЗДІБНОСТІ, ЯКОСТІ, РОЗВИТОК}

У статті здійснено аналіз соціальної обдарованості в теоретичному $і$ прочесуальному (діяльнісному) аспектах. Визначено специфіку соціальноі обдарованості, зумовлену природними задатками й набутими здібностями (соціальний інтелект, емоційний інтелект, здатність до міжособистісної $i$ колективної взаємодіï) особистості.

Ключові слова: сочіальна обдарованість, соціальний інтелект, емоційний інтелект, соиіальна діяльність.
Статья посвящена анализу сочиальной одаренности в теоретическом и процессуальном (деятельностном) аспектах. Определена спещифика сочиальной одаренности, обусловленная природньми задатками и приобретенными способностями (социальный интеллект, эмоциинальный интеллект, способность кмежличностному и коллективному взаимодействию) личности.

Ключевые слова: сочиальная одаренность, сочиальный интеллект, эмоциональный интеллект, социиальная деятельность. 